\title{
EVALUASI DRUG RELATED PROBLEMS (DRPS) PENGOBATAN DIARE PADA PASIEN BALITA DI INSTALASI RAWAT INAP RUMAH SAKIT AZRA BOGOR
}

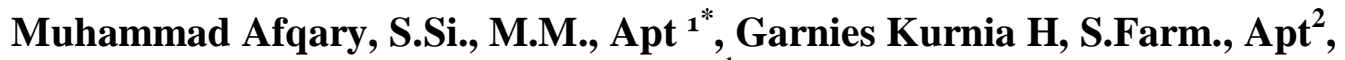 \\ Sischa
}

1Program Studi S1 Farmasi Sekolah Tinggi Teknologi Industri dan Farmasi, Bogor

${ }^{2}$ Rumah Sakit Azra Bogor

*Korespondensi: afqary@gmail.com

\begin{abstract}
ABSTRAK
Diare merupakan suatu penyakit yang ditandai dengan bertambahnya frekuensi Buang Air Besar lebih dari 3 kali dalam satu hari disertai dengan konsistensi tinja cair dan disertai ada atau tidaknya darah atau lendir. Dalam penatalaksanaan diare balita yang menjalani perawatan akan berdampak munculnya masalah dalam pemberian obat Drug Related Prolems (DRPs). Telah dilakukan penelitian pada penderita diare balita yang dirawat di instalasi rawat inap Rumah Sakit Azra Bogor periode 1 Januari 2018 sampai 31 Desember 2018. Dengan teknik pengumpulan data secara retrospektif dan dianalisis secara deskriptif, metode yang dipakai menggunakan rumus Slovin dan didapat sampel sebanyak 152 pasien dengan rentan usia 0-5 tahun. Hasil pengumpulan dan pengolahan data menunjukkan bahwa di Rumah Sakit Azra Bogor Jenis kelamin terbanyak adalah laki-laki 85 orang dan perempuan 67 orang. Terapi obat yang paling banyak diterima oleh penderita diare adalah golongan probiotik yaitu $100 \%$ sedangkan obat lain yang digunakan bersamaan dengan obat diare untuk terapi diare adalah antibiotik 90,78\%. Hasil evaluasi menunjukkan bahwa DRPs yang potensial yaitu interaksi obat yang dengan interaksi bermakna klinik $0,00 \%$ dan tidak bermakna klinik 48\%, terapi tanpa indikasi 20\%, indikasi tanpa terapi $7 \%$, overdosis $25 \%$, dosis subterapetik $10 \%$, pemilihan obat yang kurang tepat $0,00 \%$, reaksi obat yang tidak dikehendaki $0,00 \%$, kegagalan menerima obat $0,00 \%$.
\end{abstract}

Kata kunci: Diare, Drug Related Problems, retrospektif, pasien balita

\begin{abstract}
Diarrhea is a disease characterized by increasing frequency of defecation more than 3 times a day accompanied by the consistency of liquid stool and accompanied by the presence or absence of blood or mucus. In the management of pediatric diarrhea undergoing treatment will have an impact on the emergence of problems in drug delivery Drug Related Problems (DRPs). A study was conducted on diarrhea patients pediatric under five who were treated in the inpatient installation of the Azra Bogor Hospital for the period of 1 January 2018 to 31 december 2018. With retrospective data collection techniques and analyzed descriptively, the method used used the Slovin formula and obtained a sampel of 152 patients with a vulnerable age of 0-5 years. The result of data collection and processing showed that at Azra Bogor Hospital there were at most 85 men and 67 women. The most accepted drug therapy by diarrhea sufferers is the probiotic group that is $100 \%$ while other drugs used in conjunction with diarrhea for diarrhea therapy are antibiotics $90,78 \%$. Evaluation result showed that potential DRPs were drug interactions with clinically significant interactions $0,00 \%$ and clinically insignificant $48 \%$, therapies without indications $20 \%$, indications without therapy $7 \%$, overdoses $25 \%$, subtherapetic doses $10 \%$, drug selection that was inappropriate $0,00 \%$, adverse drug reaction $0,00 \%$, failure to receive drug $0,00 \%$.
\end{abstract}

Keywords: Diarrhea, Drug Related Problems, retrospectives, pediatric patients 


\section{PENDAHULUAN}

Penyakit diare sampai saat ini masih menjadi masalah kesehatan dunia terutama di negara yang sedang berkembang. Besarnya masalah tersebut terlihat dari tingginya angka kesakitan dan kematian akibat diare. WHO memperkirakan 4 milyar kasus terjadi pada tahun 2000 dan 2,2 juta diantaranya meninggal, sebagian besar anak-anak dibawah umur 5 tahun. Hal ini sebanding dengan 1 anak meninggal setiap 15 detik karena diare.

Di Indonesia, diare masih merupakan salah satu masalah kesehatan masyarakat utama. Hal ini disebabkan masih tingginya angka kesakitan dan menimbulkan banyak kematian terutama pada bayi dan balita, serta sering menimbulkan Kejadian Luar Biasa (KLB). Kriteria KLB yaitu adanya peningkatan kejadian kesakitan/kematian karena diare secara terus menerus selama 3 kurun waktu berturut-turut (jam, hari, minggu). Peningkatan kejadian/ kematian kasus diare 2 kali atau lebih dibandingkan jumlah kesakitan/ kematian karena diare yang biasa terjadi pada kurun waktu sebelumnya (jam, hari, minggu).

Drug related problems adalah sebuah kejadian atau problem yangmelibatkan terapi obat penderita yang mempengaruhi pencapaian outcome. DRPs terdiri dari DRP aktual dan DRP potensial. DRP Aktual adalah problem yangsedang terjadi berkaitan dengan terapi obat yang sedang diberikan pada penderita.Sedangkan DRP potensial adalah problem yang diperkirakan akan terjadi yangberkaitan dengan terapi obat yang sedang digunakan oleh penderita (Seto et al,2004).

\section{METODE PENELITIAN}

Pengambilan data sampel diambil secara restrospektif dari data rekam medis di Instalasi Rawat Inap Rumah Sakit Azra Bogor yang memenuhi kriteria inklusi dan ekslusi selama menjalani perawatan pada periode 1 Januari 2018 sampai 31 Desember 2018.

Adapun tahap-tahap dalam pengumpulan data ini meliputi :

a. Pencatatan nomor registrasi rekam medis pasien, nama pasien, usia pasien, jenis kelamin pasien dan diagnosa pasien yang di dapat dari Instalasi Rawat Inap Rumah Sakit Azra Bogor

b. Pengumpulan data diperoleh dari nomor rekam medis yang ada di Instalasi Rawat Inap Rumah Sakit Azra Bogor untuk melihat status pasien yang tercatat di rekam medis yang ada di ruang penyimpanan status pasien atau ruang rekam medik.

c. Data pencatatan pada lembar laporan yang meliputi :

- Data demografi pasien : Nomor registrasi rekam medis pasien, nama pasien, usia pasien, berat bada pasien dan jenis kelamin pasien.

- Data gambaran klinis : Diagnosa pasien, suhu badan pasien, keluhan pasien, jenis obat yang diberikan, dosis dan frekuiensi pemberian obat, lama pemberian obat dan data pengujian hasil laboratorium.

d. Pengolahan data

Data yang diperoleh kemudian diskrining, data dianalisis dan dikelompokkan berdasarkan jenis kelamin, golongan dan jenis obat yang diberikan, klasifikasi diare yang mengalami komplikasi dehidrasi ringan, dehidrasi ringan sedang, dehidrasi berat dan analisi DRPs yang terjadi.

\section{HASIL DAN PEMBAHASAN HASIL}

Dari penelitian yang dilakukan diperoleh data sebagai berikut:

Tabel 1. Jumlah penderita Diare berdasarkan pengelompokkan jenis kelamin selama periode 1 Januari 2018 sampai 31 Desember 2018

\begin{tabular}{ccc}
\hline Jenis Kelamin & Jumlah Penderita & Persentase Penderita \\
\hline Laki-Laki & 85 & $56,00 \%$ \\
\hline
\end{tabular}


56 | Muhammad Afqary et al., (Evaluasi Drug Related Problems (DRPs...)

\begin{tabular}{ccc}
\hline Perempuan & 67 & $44,00 \%$ \\
\hline TOTAL & $\mathbf{1 5 2}$ & $\mathbf{1 0 0 . 0 0 \%}$
\end{tabular}

Keterangan: Persentase penderita merupakan jumlah penderita laki-laki atau perempuan dibagi dengan total penderita, dikali $100 \%$.

Tabel 2. Jumlah Penderita Diare Berdasarkan Usia Periode 1 Januari 2018 - 31 Desember 2018

\begin{tabular}{cccc}
\hline Usia & Jenis Kelamin & Jumlah Penderita & Persentase Penderita \\
\hline 0-1 Tahun & Laki-laki & 31 & $20,39 \%$ \\
& Perempuan & 25 & $16,44 \%$ \\
\hline \multirow{2}{*}{ 1-2 Tahun } & Laki-laki & 24 & $15,78 \%$ \\
& Perempuan & 21 & $13,81 \%$ \\
\hline 2-3 Tahun & Laki-laki & 16 & $10,52 \%$ \\
& Perempuan & 15 & $9,90 \%$ \\
\hline \multirow{2}{*}{ 3-4 Tahun } & Laki-laki & 5 & $3,28 \%$ \\
& Perempuan & 5 & $3,28 \%$ \\
\hline \multirow{2}{*}{ 4-5 Tahun } & Laki-laki & 7 & $4,60 \%$ \\
& Perempuan & 3 & $2,00 \%$ \\
\hline & TOTAL & $\mathbf{1 5 2}$ & $\mathbf{1 0 0 . 0 0 \%}$
\end{tabular}

Keterangan :

Persentase penderita merupakan jumlah penderita berdasarkan usia, dibagi dengan total penderita 152 , dikali $100 \%$.

Tabel 3. Golongan dan Jenis Obat Diare yang Diberikan Pada Penderita Diare Usia 0-5 Tahun Periode 1 Januari 2018 - 31 Desember 2018

\begin{tabular}{cccc}
\hline Golongan & Jenis Obat & $\begin{array}{c}\text { Jumlah } \\
\text { Penderita }\end{array}$ & $\begin{array}{c}\text { Persentase } \\
\text { Penderita }\end{array}$ \\
\hline $\begin{array}{c}\text { Larutan } \\
\text { rehidrasi oral }\end{array}$ & Oralit & 7 & $4,60 \%$ \\
\hline & Total & $\mathbf{7}$ & $\mathbf{4 , 6 0 \%}$ \\
\hline Zink & Zink sirup & 57 & $37,5 \%$ \\
& Zink drop & 61 & $40,13 \%$ \\
\hline \multirow{2}{*}{ Probiotik } & Total & $\mathbf{1 1 8}$ & $\mathbf{7 7 , 6 3 \%}$ \\
& Lacto-B* & 84 & $55,27 \%$ \\
& Interlac drop* & 40 & $26,31 \%$ \\
& Probiokid* & 28 & $18,42 \%$ \\
\hline Antidiare & Total & $\mathbf{1 5 2}$ & $\mathbf{1 0 0 , 0 0 \%}$ \\
\hline & Smecta* & 16 & $10,52 \%$ \\
\hline
\end{tabular}

Keterangan :

Jumlah Penderita adalah banyaknya penderita yang menerima obat tersebut Persentase penderita merupakan jumlah penderita, dibagi dengan total penderita 152, dikali $100 \%$.

*Obat Paten

Tabel 4. Golongan dan jenis obat lain yang digunakan bersaman dengan Obat Diare pada Penderita Diare Usia 0-5 Tahun 
57 Muhammad Afqary et al., (Evaluasi Drug Related Problems (DRPs...)

Periode 1 Januari 2018 - 31 Desember 2018

\begin{tabular}{|c|c|c|c|c|}
\hline No & Golongan Obat & Jenis Obat & $\begin{array}{l}\text { Jumlah } \\
\text { Penderita }\end{array}$ & Persentase Penderita \\
\hline \multirow[t]{3}{*}{1} & Obat saluran & Ranitidin inj & 26 & $17,10 \%$ \\
\hline & $\begin{array}{c}\text { pencernaan (Antasida } \\
\text { dan Ulkus) }\end{array}$ & Omeprazol inj & 20 & $13,15 \%$ \\
\hline & \multicolumn{2}{|l|}{ Total } & 46 & $30,25 \%$ \\
\hline 2 & $\begin{array}{l}\text { Obat Antiemetik } \\
\text { (Mual, Muntah) }\end{array}$ & $\begin{array}{l}\text { Ondancentron } \\
\text { inj }\end{array}$ & 117 & $76,97 \%$ \\
\hline \multicolumn{3}{|c|}{ Total } & 117 & $76,97 \%$ \\
\hline \multirow[t]{4}{*}{3} & Obat Analgetik & $\begin{array}{l}\text { Paracetamol } \\
\text { inf }\end{array}$ & 37 & $24,34 \%$ \\
\hline & & $\begin{array}{l}\text { Paracetamol } \\
\text { Drop }\end{array}$ & 7 & $4,60 \%$ \\
\hline & & $\begin{array}{l}\text { Paracetamol } \\
\quad \text { sirup }\end{array}$ & 20 & $13,16 \%$ \\
\hline & Total & & 64 & $42.10 \%$ \\
\hline \multirow[t]{9}{*}{4} & Obat Antibiotik & Ceftazidime inj & 4 & $2,63 \%$ \\
\hline & & Cefixime sirup & 2 & $1,31 \%$ \\
\hline & & Ampicillin inj & 21 & $13,81 \%$ \\
\hline & & Ceftriaxone inj & 97 & $63,28 \%$ \\
\hline & & Metronidazol inf & 3 & $1,97 \%$ \\
\hline & & Nystatin susp & 3 & $1,97 \%$ \\
\hline & & Amikacin inj & 3 & $1,97 \%$ \\
\hline & & Cefotaxime inj & 5 & $3,30 \%$ \\
\hline & Total & & 138 & $90,78 \%$ \\
\hline
\end{tabular}

Keterangan:

Jumlah penderita adalah banyaknya penderita yang menerima obat tersebut Persentase penderita merupakan jumlah penderita dibagi dengan total penderita 152, dikali $100 \%$

Tabel 5. Kasus DRPs yang Terjadi Pada Penderita Diare usia 0-5 Tahun Periode 1 Januari 2018 - 31 Desember 2018

\begin{tabular}{llcc}
\hline No & \multicolumn{1}{c}{ DRPs } & Jumlah Kasus & Persentase Kasus \\
\hline 1 & Interaksi Obat & 0 & \\
& • Bermakna Klinis & 48 & 0,00 \\
& • Tidak Bermakna Klinis & 20 & $48 \%$ \\
\hline 2 & Terapi Tanpa Indikasi & 7 & $20 \%$ \\
\hline 3 & Indikasi Tanpa Terapi & 25 & $7 \%$ \\
\hline 4 & Overdosis & 10 & $25 \%$ \\
\hline 5 & Dosis Subterapetik & 0 & $10 \%$ \\
\hline 6 & Pemilihan Obat Yang Kurang Tepat & 0 & 0,00 \\
\hline 7 & Reaksi Obat Yang Tidak & 0 & 0,00 \\
& Dikehendaki & $\mathbf{1 0 0}$ & 0,00 \\
\hline 8 & Kegagalan Menerima Obat & & $\mathbf{1 0 0 . 0 0 \%}$ \\
\hline & $\quad$ Total & &
\end{tabular}

Keterangan: 
Persentase merupakan jumlah kasus DRPs tertentu dibagi dengan total kasus DRPs, dikali $100 \%$.

\section{PEMBAHASAN}

Selama periode ini, bayi sepenuhnya tergantung pada perawatan dan pemberian makan oleh ibunya. Dan masa bayi merupakan bulan pertama kehidupan kritis karena bayi akan mengalami adaptasi terhadap lingkungan, perubahan siklus darah, serta mulai berfungsinya organorgan tubuh pada pasca neonatus bayi akan mengalami pertumbuhan yang sangat cepat. Insiden paling tinggi pada golongan jenis kelamin laki-laki yaitu sebanyak $56 \%$ dan jenis kelamin perempuan $44 \%$.

Kebanyakan episode diare terjadi pada usia 2 tahun pertama kehidupan, insiden paling tinggi pada golongan umur 0-1 tahun (Tabel 2). Pada masa diberikan makanan pendamping. Pola ini menggambarkan kombinasi efek penurunan kadar antibodi ibu, kurangnya kekebalan aktif bayi, pengenalan makanan yang kemungkinan terpapar bakeri tinja dan kontak langsung dengan tinja manusia atau binatang pada saat bayi merangkak. Kebanyakan kuman usus merangsang paling tidak sebagian kekebalan melawan infeksi atau penyakit yang berulang, yang membantu menjelaskan penurunannya insiden pada anak yang lebih besar dan pada orang dewasa (Depkes RI, 1999).

Berdasarkan pengelompok kan golongan dan jenis obat diare dapat diketahui bahwa obat diare yang paling banyak diberikan kepada penderita selama perawatan adalah golongan probiotik sebanyak 152 pasien (100\%) dengan jenis obat yaitu Lacto-B sebanyak 84 pasien $(55,27 \%)$, Probiokid sebanyak 28 pasien $(18,42 \%)$ dan Interlac drop sebanyak 40 pasien (26,31\%). Penggunaan zink sebanyak 118 pasien $(77,63 \%)$ dengan jenis obat yaitu Zink sirup sebanyak 57 pasien $(37,5 \%)$ dan Zink drop sebanyak 61 pasien (40,13\%). Dalam pemberian obat Antidiare Smecta sebanyak 16 pasien $(10,52 \%)$.
Sedangkan pemberian Larutan rehidrasi oral (Oralit) sebanyak 7 pasien $(4,60 \%)$.

Terdapat 4 golongan jenis obat yang digunakan bersamaan dengan obat diare pada penderita diare usis 0-5 tahun. Penggunaan yang banyak diberikan pada penderita diare, diantaranya yaitu antibiotik sebanyak 138 penderita $(90,78 \%)$ dimana antibiotik diberikan jika ada indikasi seperti mencret dengan komplikasi diare ringan, sedang, dan berat, demam, feses berdarah atau diare karena kolera, shigellosis, invasif intestinal amobiosis. Penggunaan golongan obat antiemetik (mual, muntah) banyak menggunakan Trovensis inj sebanyak 117 pasien $(76,97 \%)$ golongan ini termasuk kedalam obat golongan penghambat pompa proton. Penggunan analgetik paling banyak menggunakan golongan Paracetamol sebanyak 64 pasien $(42,10 \%)$. Golongan antagonis reseptor $\mathrm{H} 2$ yaitu Ranitidin inj sebanyak 26 pasien $(17,10 \%)$ dan Omeprazol inj 20 pasien $(13,15 \%)$.

Berdasarkan hasil data interaksi obat yang terjadi pada pasien diare usia 0-5 tahun periode 1 Januari 2018 sampai 31 Desember 2018 yang berinteraksi secara klinik tidak ditemukan $(0,00 \%)$ tetapi yang terjadi interaksi tidak bermakna klinik sebanyak 48 orang (48\%).

Dari hasil evaluasi ditemukan terapi tanpa indikasi sebanyak 20 kasus (20\%) dari total kasus yang ditemukan sesuai dengan keluhan pasien pada rekam medik.

Dari hasil evaluasi ditemukan beberapa kasus tentang indikasi tanpa terapi yaitu 7 kasus $(7 \%)$. Kasus tersebut diantaranya pasien mengalami demam dan muntah tetapi tidak diberikan pengobatan.

Penilaian overdosis dilakukan berdasarkan dosis maksimal dari literatur atau pustaka. Setelah dilakukan penelitian pada pasien diare usia 0-5 tahun selama periode 1 Januari 2018 sampai 31 Desember 2018, ditemukan beberapa kasus 
tentang overdosis yaitu sebanyak 25 kasus $(25 \%)$.

Pada dasarnya, dosis obat dipertimbangkan berdasarkan penyakit dan informasi riwayat pasien. Berdasarkan Tabel 2 diatas kasus dosis subterapetik ditemukan sebanyak 10 kasus (10\%) pada penderita diare selama 1 Januari 2018 sampai 31 Desember 2018.

Dalam penelitian yang dilakukan tidak ditemukan kasus Pemilihan obat yang kurang tepat, tidak ditemukan kasus Reaksi obat yang tidak dikehendaki dan tidak ditemukan kasus Kegagalan menerima obat.

\section{SIMPULAN}

Berdasarkan hasil penelitian Evaluasi Drug Related Problems (DRPs) yang sudah dilakukan secara retrospektif pada pasien diare usia 0-5 tahun di Instalasi Rawat Inap Rumah Sakit Azra Bogor tahun 2018. Terjadinya DRPs secara rinci dapet dijabarkan sebagai berikut:

a. Sosiodemografi jenis kelamin yang diteliti yaitu usia 0-5 tahun anak laki-laki lebih banyak terkena diare yaitu sebanyak $56 \%$ sedangkan anak perempuan $44 \%$.

b. Berdasarkan pengelompokkan usia, diare terjadi paling tinggi pada usia 0-12 bulan, yaitu pada anak laki-laki 31 pasien dan anak perempuan 25 pasien. Serta pengelompokkan golongan dan jenis obat diare dapat diketahui obat yang paling banyak digunakan yaitu Probiotik 152 pasien (100\%). Golongan obat dan jenis obat lain yang digunakan bersamaan dengan obat diare yang terbanyak digunakan yaitu obat Antibiotik 138 pasien $(90,78 \%)$.

c. Kasus DRPs yang terjadi pada penderita diare usia 0-5 tahun selama periode 1 Januari 2018 - 31 Desember 2018. Pada potensi interaksi obat terdapat 48 yang terdiri dari interaksi bermakna klinik 0 kasus $(0,00 \%)$ dan interaksi tidak bermakna klinik 48 kasus (48\%). Terapi tanpa indikasi 20 kasus (20\%), Indikasi tanpa terapi 7 kasus (7\%), Overdosis 25 kasus (25\%), Dosis subterapetik 10 kasus (10\%), Pemilihan Obat Yang
Kurang Tepat 0 kasus $(0,00 \%)$, Reaksi Obat Yang Tidak Dikehendaki 0 kasus $(0,00 \%)$ dan Kegagalan Menerima Obat 0 kasus $(0,00 \%)$.

\section{DAFTAR PUSTAKA}

[1] Adisasmito, W, (2007).http://reposit ory.ui.ac.id/contents/koleksi/2/f09997 9f9dad58879019cd029556381fb6730 c5d.pdf

[2] American Society of Health-system Pharmacist, 1998. Medication Therapy and Patien Care : Organization and Delivery of ServiceStatements.

(http://www.ashp.org.DocLibrary/Bes tPratices/OrgStPharmCare.aspx).

Diakses 25 Februari 19 Jam 16:00.

[3] Asititi, P.M.A; Mukaddas, A; Safarudin(2017)http://jurnal.untad.ac. id/jurnal/index.php/Galenika/article/d ownload/8140/6454

[4] Chaliks, R; St. Ratnah : Karim, D (2018)http://journal.poltekkesmks.ac.i d/ojs2/index.php/mediafarmasi/article /download/83/46. Diakses 20 Desember 2018 Jam 10:15

[5] Cippole, RJ;Strand,L.M, Morley, P.C(2004), Pharmaceutical Care Pratice: The Clinical,s Guid. Edii k-2. New York :McGrow-Hill. Diunduh dari

http://www.ebook.downappz.com/?pa ge=book\&id=E2CGKZR7P6\#downlo ad. Diakses 02 Maret 19 Jam 19:00

[6] Depkes RI, 2005. Pharmaceutical Care Untuk Penyakit Diare. Jakarta:Departemen Kesehatan RI.

[7] Depkes RI, 2009. Kategori umur menurut Departemen Kesehatan Republik Indonesia tahun 2009.

[8] Depkes RI, 2011. Buku Saku Petugas Kesehatan LINTAS DIARE. Jakarta Depkes RI. 
$60 \mid$ Muhammad Afqary et al., (Evaluasi Drug Related Problems (DRPs...)

[9] Depkes RI, 2010. Peraturan Mentri Kesehatan Republik Indonesia Nomor 147/Menkes/PER/I/2010 tentang Perizinan Rumah Sakit. Diunduh dari: http://pelayanan.jakarta.go.id/downlo ad/regulasi/peraturan-menterikesehatan-nomor-147-menkes-per-i2010-tentang-perizinan-rumahsakit.pdf. Diakses 24 Februari 2019 Jam 20:29

[10] Kemenkes RI, 2012. Profil kesehatan Indonesia 2012.http://www. depkes.go.id/resources/download/pus datin/profil-kesehatanindonesia/profil-kesehatan-indonesia2012.pdf. Diakses 19 Maret 2019 Jam 23:05

[11] Komaludin, D. 2017. Evaluasi Drug Related Problems (DRPs) dalam Peresepan Untuk Pengobatan Diare Pada Pasien Balita di Instalasi Rawat Inap RS BLUD Sekarwangi Sukabumi Periode 1 Januari sampai 31 Desember 2017 (Skripsi), Bogor: Sekolah Tinggi Teknologi Industri dan Farmasi (STTIF).

[12] Lubis, E. 2019. Evaluasi Ketepatan Pengobatan Diare Pada Balita Usia 05 Tahun di Instalasi Rawat Inap Rumah Sakit Azra Bogor Periode Januari-Juli 2018 (Skripsi), Bogor: Sekolah Tinggi Teknologi Industri dan Farmasi (STTIF).

[13] Mutchler, 2006. Dinamika Obat : Farmakologi dan Toksikologi : Penerbit Institut Teknologi Bandung (ITB), Bandung.

[14] Ma'arij,N.F.N, 2009. Identifikasi Drug Related Problems (DRPs) Dalam Pengobatan Diare Pada Anak Di Instalasi Rawat Inap Rumah Sakit Umum Daerah Wonogiri Tahun 2007 http://eprints.ums.ac.id/5085/1/ K100040188.pdf. Diakses 27 Februari 19 Jam 20:00.
[15] Permenkes RI, 2008. Permenkes 269 tentang Rekam Medis 2008. https://pormiki.or.id/peraturanmenteri-kesehatan-republikindonesia-nomor269menkesperiii2008/. Diakses 19 Maret 2019 Jam 23:17

[16] Santi, I; Herman, H: Aninditia, D.D (2017). http://jurnal.farmasi.umi.ac.id/index. php/assyifaa/article/download/277/pdf

[17] Setiawati A, 2007. Interaksi Obat. Dalam Farmakologi dan Terapi, Edisi 5. Jakarta:Fakultas Kedoktoran Univarsitas Indonesia.

[18] Sevilla et. Al., 1960:82. https://www.statistikian.com/2017/12/ hitung-rumus-slovinsampel.html/amp. Diakses 20 Maret 2019 Jam 18:30

[19] Stockley, I.H. (2008). Stockley's Drug Interaction. Edisi kedelapan. Great Britain: Pharmaceutical Press. Halaman 194,295.

[20] Siregar, Charles J.P. 2004. Farmasi Rumah Sakit. Penerbit Buku Kedokteran EGC. jakarta

[21] Subhan,M, 2015. Laboratorium Farmakologi Fakultas Farmasi Universitas Muslim Indonesia Makassar : Interaksi obat. https://caridokumen.com/download/la poran-interaksi-obat_5a45e148b7d7bc7b7adc5752_pdf. Diakses 24 Februari 19 Jam 20:36.

[22] Triwulan II, 2011. Buletin Jendela Data Dan Informasi Kesehatan, Kemenkes RI. http://www.depkes.go.id/download.ph p?file=download/pusdatin/buletin/bul etin-diare.pdf. Diakses 24 Februari 19 Jam 19:59. 
61 Muhammad Afqary et al., (Evaluasi Drug Related Problems (DRPs...)

[23] Wutsqo,N.U, 2016. Identifikasi Drug Related Problems (DRPs) Diare Akut Infeksi Pada Pasien Pediatri Di Instalasi Rawat Inap RS “X” Di Kota Tangerang Selatan Periode Januari -
Desember 2015 http://repository.uinjkt.ac.id/dspace/bi tstream/123456789/32426/1/NABILA H URWATUL WUTSQO-FKIK.pdf. diakses 27 Februari 19 Jam 22:33. 